\title{
Deferasirox-induced urticarial vasculitis in a patient with myelodysplastic syndrome*
}

\author{
Asude Kara Polat ${ }^{1}$ \\ Volkan Karakus ${ }^{3}$
}

\author{
Asli Akin Belli \\ Yelda Dere ${ }^{4}$
}

DOI: http:/ /dx.doi.org/10.1590/abd1806-4841.20176688

\begin{abstract}
Deferasirox is an iron chelator agent used in the treatment of diseases with iron overload, such as thalassemia and myelodysplastic syndrome. Although the majority of adverse reactions of deferasirox involve gastrointestinal symptoms and increase in serum creatinine and transaminases, skin rashes, such as maculopapular and urticarial eruptions, have also been reported. This study reports a case of myelodysplastic syndrome with urticarial vasculitis due to deferasirox therapy. Drug eruption was been confirmed by means of a challenge test, together with histopathological and clinical findings. To the best of our knowledge, we report the first case of deferasirox-induced urticarial vasculitis. Physicians should be aware of the possibility of urticarial vasculitis on deferasirox therapy and the fact that the discontinuation of the drug generally results in improvement.
\end{abstract}

Keywords: Drug eruptions; Myelodysplastic-myeloproliferative diseases; Vasculitis

\section{INTRODUCTION}

Deferasirox is an iron chelator agent used in the treatment of the diseases with iron overload due to a large number of blood transfusions. Gastrointestinal discomfort, increase in serum creatinine and transaminases, and agranulocytosis are the most common adverse reactions of deferasirox therapy. ${ }^{1,2}$ Skin rashes are also well-known adverse reactions, most of which are characterized by maculopapular eruption or urticaria. ${ }^{2-4}$ This study reports a case of myelodysplastic syndrome with deferasirox-induced urticarial vasculitis.

\section{CASE REPORT}

A 77-year-old female presented an edema on her eyelids and lips, along with an erythematous rash on the trunk and limbs for 2 days in the Dermatology Outpatient Clinic. Upon physical examination, bilateral edema on the eyelids and lips, and widespread, erythematous, and palpable purpuric papules on the trunk and limbs were observed (Figures 1 and 2). The patient had diabetes mellitus and coronary artery disease, and had therefore been taking metformin, furosemide, and aldactazide, as well as the combination of spironolactone and hydrocholorothiazide for 3 years. In addition, the patient was diagnosed with myelodysplastic syndrome 6 months ago, and darbepoetin alfa, thalidomide, and deferasirox therapies had been implemented for the prior 6 months, 3 months, and 4 days, respectively. Laboratory tests were as follows; hemoglobin: $9.02 \mathrm{~g} / \mathrm{dL}$, white blood cells: $1600 / \mathrm{mm}^{3}$, platelets: $28000 / \mathrm{mm}^{3}$, C-reactive protein: $27.43 \mathrm{mg} / \mathrm{dL}$, fasting blood glucose: $204 \mathrm{mg} / \mathrm{dL}$, urea: $171 \mathrm{mg} / \mathrm{dL}$, and creatinine: $1.54 \mathrm{mg} / \mathrm{dL}$. Serological tests were negative for Hepatitis B, Hepatitis C, and HIV. A punch biopsy was obtained from the skin lesions. Histopathological examination showed eythrocyte extravasation, neutrophilic infiltration with eosinophils, and fibrinoid necrosis in the vessel walls of the dermis (Figure 3). Histopathological examination and clinical findings were compatible with vasculitic drug eruption. Unfortunately, we could

Work submitted on 06.11.2016

Approved by the Advisory Board and accepted for publication on 10.01.2017

* Work performed at the Department of Dermatology, Mugla Sitki Kocman University Training and Research Hospital, Mugla, Turkey. Financial support: None

Conflict of interest: None

Department of Dermatology, Istanbul Training and Research Hospital - Istanbul, Turkey.

Department of Dermatology, Mugla Sitki Kocman University Training and Research Hospital - Mugla, Turkey.

Department of Hematology, Mugla Sitki Kocman University Training and Research Hospital - Mugla, Turkey.

Department of Pathology, Mugla Sitki Kocman University, Faculty of Medicine - Mugla, Turkey. 


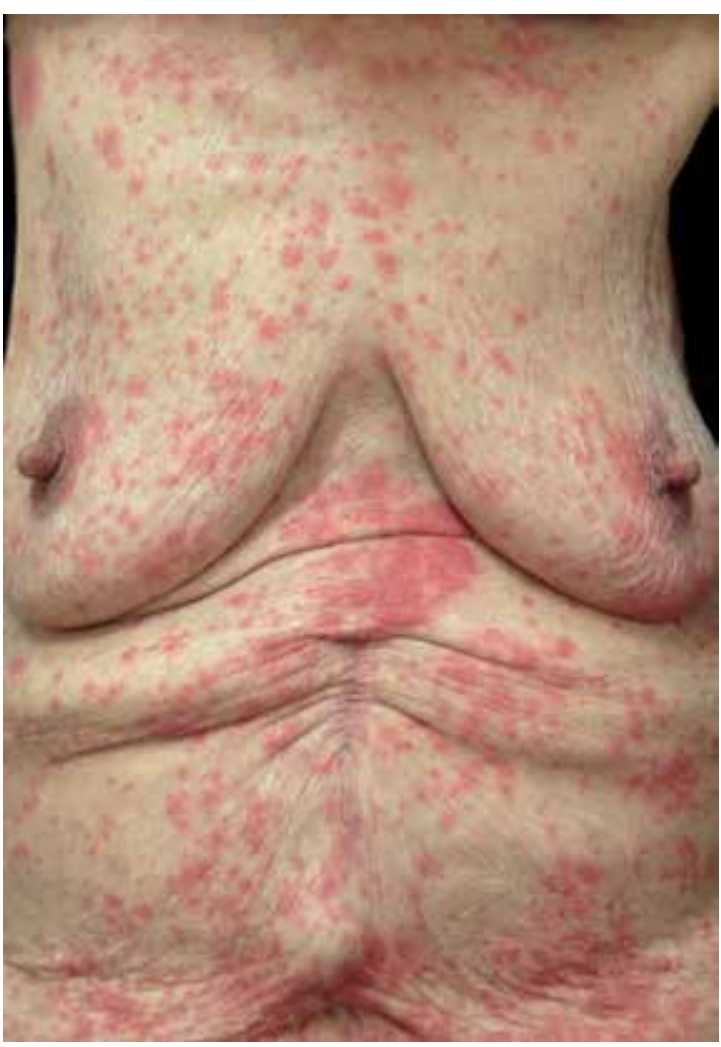

FigURE 1: Widespread erythematous, purpuric papules, and plaques, diameters ranging $0.5 \mathrm{~cm}$ to $2 \mathrm{~cm}$ on the trunk

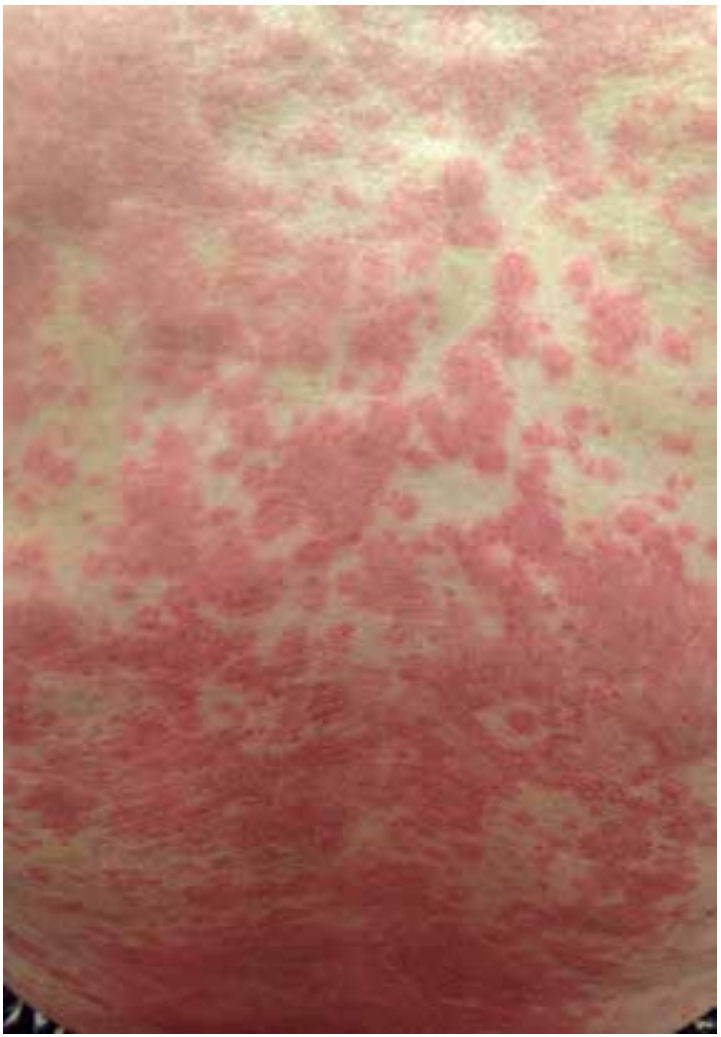

FigURE 2: Widespread erythematous, purpuric papules, and plaques, diameters ranging $0.5 \mathrm{~cm}$ to $2 \mathrm{~cm}$ on the back not get a direct immunofluorescence (DIF) examination of the lesional skin. We find no other etiological factor that was responsible for leukocytoclastic vasculitis, such as infections, connective tissue diseases, neoplasms, and genetic disorders. Since thalidomide and deferasirox therapies could be responsible for the eruption, we interrupted these therapies and began $40 \mathrm{mg}$ /day methylprednisolone and antihistamine therapies parentally. The rash and edema cleared within 5 days. After 10 days of eruption, we reintroduced the deferasirox therapy, and the rash relapsed in a shorter time. We then discontinued the deferasirox therapy permanently. Thalidomide therapy was also reintroduced and no skin rash was observed. The vasculitic eruption seen in our patient was attributed to the deferasirox therapy.

\section{DISCUSSION}

Drug-induced-vasculitis comprises $\sim 30 \%$ of all cutaneous vasculitides. The list of responsible drugs is gradually increasing with the emergence of new drugs. This is mostly observed with penicillins, non-steroidal anti-inflammatory drugs (NSAIDs), sulfonamides, and cephalosporins (Table 1) ${ }^{5,6}$ In the pathogenesis, the formation of immune complexes and the induction of the immune response have been proposed. Drug-induced vasculitis generally occurs within 7-21 days. However, the eruption may appear in less than 3 days with a reuptake of the responsible drug. The course of

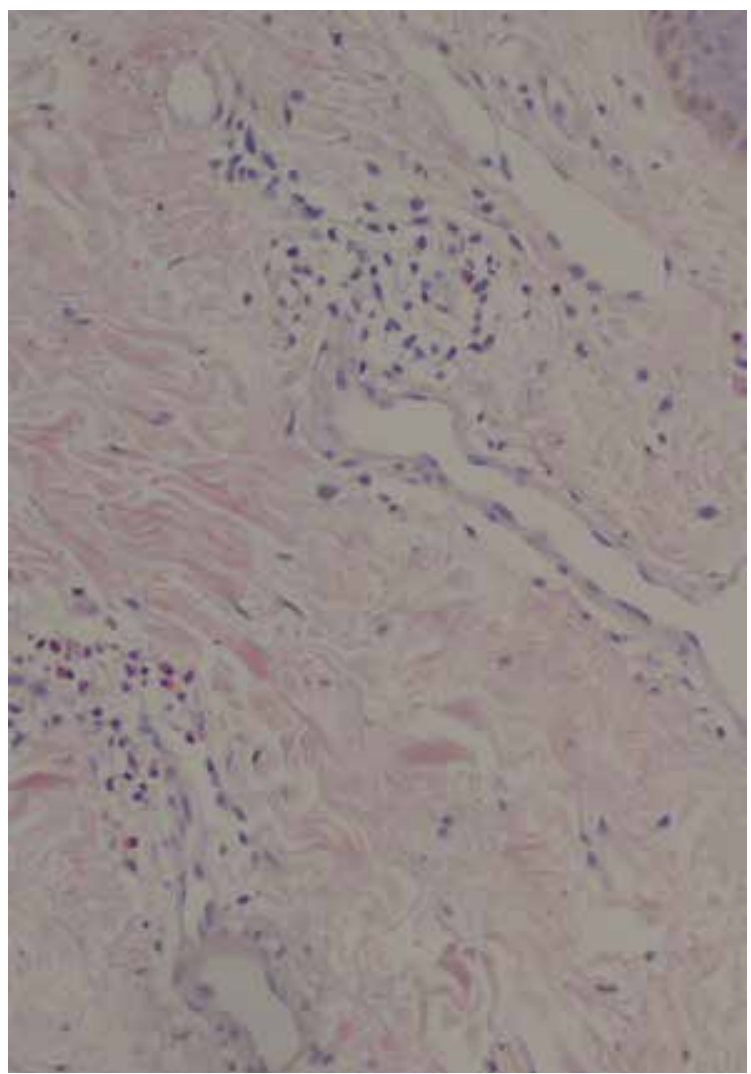

Figure 3: Histopathological examination showing erythrocyte extravasation, neutrophilic infiltration with eosinophils, and fibrinoid necrosis in the vessel walls of the dermis (Hematoxylin \& eosin, X200) 


\begin{tabular}{|c|c|}
\hline Antibiotics & $\begin{array}{l}\text { Penicillins, cephalosporins, } \\
\text { sulfonamides, minocycline, } \\
\text { vancomycin, macrolides }\end{array}$ \\
\hline Rheumatological & $\begin{array}{l}\text { NSAIDs, allopurinol, sulfony- } \\
\text { lureas }\end{array}$ \\
\hline Cardiac & $\begin{array}{l}\text { Acetylsalicylic acid, warfa- } \\
\text { rin, streptokinase, diuretics, } \\
\text { amiodarone, antihypertensives }\end{array}$ \\
\hline Neurological and psychiatry & $\begin{array}{l}\text { Anticonvulsants, phenothi- } \\
\text { azines, antidepressants }\end{array}$ \\
\hline Oncology & $\begin{array}{l}\text { Cytarabine, dacarbezine, } \\
\text { gemcitabine }\end{array}$ \\
\hline Immunosuppressants & $\begin{array}{l}\text { Methotrexate, cyclosporine, } \\
\text { azathioprine }\end{array}$ \\
\hline Biologics & $\begin{array}{l}\text { Anti-TNF agents, rituximab, } \\
\text { interferons, G-CSF, Bortezomib }\end{array}$ \\
\hline Miscellaneous & $\begin{array}{l}\text { Retinoids, methamphetamine, } \\
\text { insulin, metformin, vitamins, } \\
\text { leukotriene inhibitors, oral } \\
\text { contraceptives, vaccines, prop- } \\
\text { ylthiouracil }\end{array}$ \\
\hline
\end{tabular}

NSAIDs: Nonsteroidal anti-inflammatory drugs, Anti-TNF: Anti-tumor necrosis factor, G-CSF: Granulocyte-colony stimulating factor Source: Revuz J, et al. $2012^{5}$ and Cox NH, et al. $2010^{6}$

drug-induced-vasculitis is better than idiopathic vasculitis, in which the discontinuation of the responsible drug is usually sufficient. ${ }^{5,7}$

Deferasirox has recently become popular with the advantage of oral use and safety. Although deferasirox is a highly tolerable drug, various adverse reactions have been stated. According to data from the literature, three case reports with skin rash due to deferasirox therapy have been reported. Of these patients, two had thalasemmia and one had acute myeloid leukemia; both had been placed on deferasirox therapy to decrease the iron overload. The skin rashes have been noted to be maculopapular erythematous plaques and urticarial lesions, especially on the trunk, and subside with the discontinuation of the drug and antihistaminic therapy. ${ }^{2-4}$ Lesional skin biopsies were not taken in the cases of Isık and Sharma et al..$^{2,4}$ Ohshita et al. reported a maculopapular eruption due to deferasirox demonstrating intraepidermal lymphocytic infiltration, epidermal spongiosis, partial vaculoar degeneration at the dermal-epidermal interface, and mild lymphocytic infiltration in the upper dermis. ${ }^{3}$ In addition, skin rash with deferasirox therapy was reported in the several observational studies. ${ }^{8,9}$

To the best of our knowledge, there is no report of vasculitic eruption due to deferasirox in the literature. We report the first case of deferasirox-induced urticarial vasculitis, proven by means of a challenge test. We want to emphasize that physicians should be aware of the possibility of urticarial vasculitis on deferasirox therapy, and the discontinuation of the drug generally results in improvement. $\square$

\section{REFERENCES}

1. Lee JW, Kang HJ, Choi JY, Kim NH, Jang MK, Yeo CW, et al. Pharmacogenetic study of deferasirox, an iron chelating agent. PLoS One. 2013;8:e64114.

2. Isik P, Yarali N, Bay A, Ozmen S, Tunc B. Type-I hypersensitivitiy reaction secondary to deferasirox intake. International Journal of Hematology \& Oncology. 2010;20:42-44.

3. Ohshita A, Nakai N, Katoh N, Konishi K. A maculopapular-type eruption associated with deferasirox administration. J Am Acad Dermatol. 2013;69:e265-7.

4. Sharma A, Arora E, Singh H. Hypersensitivity reaction with deferasirox. J Pharmacol Pharmacother. 2015;6:105-6.

5. Revuz J, Valeyrie-Allanore L. Drug Reactions. In: Bolognia JL, Jorizzo JL, Rapini RP, editors. Dermatology. St. Louis: Mosby Elsevier; 2012. p. 335-56.

6. Cox NH, Jorizzo JL, Bourke JF, Savage COS. Vasculitis, Neurophilic Dermatoses and Related Disorders. In: Burns T, Breathnach S, Cox N, Griffiths C, editors. Rook's Textbook of Dermatology. Oxford: Blackwell Publishing; 2010. p. 50.1-50.95.

7. Antiga E, Verdelli A, Bonciani D, Bonciolini V, Quintarelli L, Volpi W, et al. Druginduced cutaneous vasculitides. G Ital Dermatol Venereol. 2015;150:203-10

8. Breccia M, Alimena G. Efficacy and safety of deferasirox in myelodysplastic syndromes. Ann Hematol. 2013;92:863-70.

9. Breccia M, Finsinger P, Loglisci G, Federico V, Santopietro M, Colafigli G, et al. Deferasirox treatment for myelodysplastic syndromes: "real-life" efficacy and safety in a single-institution patient population. Ann Hematol. 2012;91:1345-9.

\author{
MAILING ADDRESS: \\ Asude Kara Polat \\ Department of Dermatology \\ Istanbul Training and Research Hospital \\ Kasap Ilyas Mah. \\ Org. Abdurrahman Nafiz Gürman Cd., \\ 34098 Istanbul, Turkey. \\ E-mail: asudekara@yahoo.com.tr
}

How to cite this article: Kara Polat A, Akin Belli A, Karakus V, Dere Y. Deferasirox-induced urticarial vasculitis in a patient with myelodysplastic syndrome. An Bras Dermatol. 2017;92(5 Suppl 1): 59-61. 